\title{
Validation of Some Bridge Pier Scour Formulae Using Field and Laboratory Data
}

\author{
Thamer Ahmed Mohamed, Megat Johari M. M. Noor, Abdul Halim Ghazali \\ and Bujang B. K. Huat \\ Department of Civil Engineering, Faculty of Engineering, Universiti Putra Malaysia \\ 43400 UPM Serdang, Selangor, Malaysia
}

\begin{abstract}
Estimation of maximum local scour depth at the bride pier site is necessary for the safety and economy of the designed bridge. Numerous formulae are available and almost all of these formulae were developed based on laboratory data. Validation of these formulae is necessary in order to ascertain which of the formulae will give a reasonable estimate of the local scour depth. In this study, four commonly cited formulae were selected for the validation process using both the laboratory and field data. They were the Colorado State University (CSU), Melville and Sutherland, Jain and Fisher, and Laursen and Toch formula. The experimental data was obtained from the laboratory model study done at University Putra Malaysia, whilst the field data were obtained from 14 bridges sites. Three statistical tests were carried out to determine the formula that gives minimum prediction errors. Comparison between the predicted and measured depth of scour from the experimental and field data showed that the Laursen and Toch and the CSU formulae appeared to give a reasonable estimate. Whilst the Melville and Sutherland and Jain and Fisher formulae appeared to over-predict the depth of the scour. This observation was supported by the statistical tests.
\end{abstract}

Key words: Scour Formulae, Physical Model, Field Data, Validation, Testing

\section{INTRODUCTION}

Many bridges failed around the world because of extreme scour around pier and abutment. For example during the spring floods of 1987, 17 bridges in New York and New England USA were damaged or destroyed by scour. In 1985, floods in Pennsylvania, Virginia, USA, destroyed 73 bridges. According to the US Department of Transportation [1], a total number of 383 bridges failed in the USA alone in year 1973. The failure of bridges due to scour will result in economical loss and may also result in losses of human life. In an extensive study of bridge failures in United States, it reported that damage to bridges and highways from major regional floods in 1964 and 1972 amounted about $\$ 100,000,000$ per event [2].

An accurate prediction of scour depth at piers is essential for the safe design of the bridge foundation because underestimation may lead to bridge failure and over estimation will lead to unnecessary construction cost. As a result, an intensive research has been conducted over the past three decades in order to develop reliable relationships for estimating maximum scour depth and also to reduce the impact of local scour on the bridge substructure. Numerous formulae for estimating maximum local scour at pier site have been developed by many researchers and the development of these formulae were based on limited data collected from physical models with conditions different from that existed in the prototype. So, the use of these formulae in design is uncertain because of the difference between site and laboratory conditions. For example, studies employed laboratory flumes, which were rectangular in cross section and had smooth fixed wall were different from natural channels that are nonrectangular with rough and mobile banks.

Validation of the various formulae using both the laboratory as well as the field data is very necessary in order to improve the prediction of maximum local scour depth at bridge piers. This may decrease unnecessary expenses for scour counter measures, making the bridge design process more efficient. This will also lead to a greater accuracy of bridge scour prediction and increased confidence in bridge design, thus increasing public safety of the users.

Coleman and Melville [3] presented evaluation on failure of three bridges in New Zealand. Johnson [4] made a comparison of pier scour formulae using field data. Koopaei and Valentine [5] compared the difference between the local scour data collected from self formed laboratory channels with predicted local scour depth computed using some formulae for estimating local scour depth at pier site. They concluded that most of the formulae over-predicted the

Corresponding Author: $\quad$ Dr. Thamer Ahmed Mohammed, Department of Civil Engineering, Faculty of Engineering, Universiti Putra Malaysia, 43400 UPM Serdang, Selangor, Malaysia Tel: 603-89466352 
maximum local scour depth. Johnson [6] developed a safety factors that are direct reflection of the allowable level of risk using a probabilistic approach.

In this study, experimental as well field data are used to validate four selected formulae for estimating local scour at bridge sites. The experimental data was obtained from the laboratory model study done at University Putra Malaysia. The field data were obtained from 14 bridges located in Pakistan, Canada and India. Unfortunately the local record of bridge failures in Malaysia due to the scour problem during flood is not available. The selected formulae used for validation process had been developed by Colorado State University (CSU), Melville and Sutherland, Jain and Fisher, and Laursen and Toch. Three statistical tests were carried out to determine the formula with minimum prediction errors. These tests are the Mean Absolute Error (MAE), Root Mean Square Error (RMSE) and Theil's Coefficient (U).

Bridge Pier Scour Formulae: Almost all the local scour formulae were developed based on the laboratory data. This is because the local scour is a very complex phenomenon that has resulted from the interaction between the flow around a bridge pier and the erodible bed surrounding it. Based on this, only very limited attempts have been successful in modelling the scour computationally. However, the formulae and models derived from these attempts are usually applied by the civil engineers to evaluate various conditions such as estimating the depth of local scour for newly designed bridges and for existing bridges experiencing local scour problems. Therefore validation of the local scour formulae by using both the laboratory and field data is necessary in order to check the accuracy of the formulae.

Four of the more commonly used and cited local scour formulae, namely the Colorado State University (CSU), Melville and Sutherland, Jain and Fisher, and Laursen and Toch formula, were examined in this study to determine their accuracy.

The Federal Highway Administration's Hydraulic Engineering Circular No. 18 (HEC-18) U.S Department of Transport [1] recommends the use of the Colorado State University (CSU) that is described below:

$$
\frac{d_{s}}{y}=2.0 K_{1} K_{2}\left(\frac{b}{y}\right)^{0.65} F r_{1}^{0.43}
$$

where, $d_{s}$ is scour depth, $y$ is flow depth at the upstream of the pier, $K_{l}$ is correction factor for pier nose shape, $K_{2}$ is correction factor for angle of attack flow, $b$ is the pier width and $F r_{l}$ is the Froude number at upstream of the pier. $L$ is the pier length. $K_{1}$ and $K_{2}$ are obtained from Table 1.
Table 1: Values of $K_{l}$ and $K_{2}$ for Different Pier Types (After Simons and Sentürk [7])

\begin{tabular}{|c|c|c|c|c|c|}
\hline \multirow[t]{2}{*}{ Type of pier } & \multirow[t]{2}{*}{$K_{I}$} & \multicolumn{4}{|c|}{$K_{2}$} \\
\hline & & $\begin{array}{l}\text { Angle of } \\
\text { flow attack }\end{array}$ & $\begin{array}{l}L / b= \\
4\end{array}$ & $\begin{array}{l}L / b= \\
8\end{array}$ & $\begin{array}{l}L / b= \\
12\end{array}$ \\
\hline Square nose & 1.1 & $0^{\circ}$ & 1.0 & 1.0 & 1.0 \\
\hline Round nose & 1.0 & $15^{\circ}$ & 1.5 & 2.0 & 2.5 \\
\hline $\begin{array}{l}\text { Circular } \\
\text { cylinder }\end{array}$ & 1.0 & $30^{\circ}$ & 2.0 & 2.5 & 3.0 \\
\hline Sharp nose & 0.9 & $45^{\circ}$ & 2.3 & 3.3 & 4.3 \\
\hline $\begin{array}{l}\text { Group } \\
\text { cylinders }\end{array}$ & 1.0 & $90^{\circ}$ & 2.5 & 3.9 & 5.0 \\
\hline
\end{tabular}

It is recommended in HEC-18 that the limiting value of $d_{S} / y$ is 2.4 for $F r_{l} \leq 0.8$ and 3.0 for $F r_{l}>0.8$.

Melville and Sutherland [8] developed a scour formula based on extensive laboratory experimentation. The formula is described below:

$d_{s}=K_{l} K_{d} K_{y} K_{a} K_{s} b$

where:

$K_{l}=$ flow intensity factor

$K_{d}=$ sediment size factor

$K_{y}=$ flow-depth factor

$K_{a}=$ pier-alignment factor

$K_{s}=$ pier-shape factor

$d_{s}$ and $b$ are as defined before

$K_{l}$ is a function of the approach velocity relative to the critical velocity and $K_{d}$ is a function of the sediment gradation expressed as the geometric standard deviation. Values of all $K$ factors are obtained from equations or graphs provided by Melville and Sutherland [8].

Neill [9] presented the design curves developed by Laursen and Toch in a form of mathematical formula. The formula for estimating the local scour depth as described by Johnson [4] is:

$d_{s}=1.35 b^{0.7} y^{0.3}$

where,

$d_{s}$ is the maximum predicted local scour depth, $b$ is the width of the bridge pier and $y$ is the flow depth.

Jain and Fisher as cited in Johnson [4] developed a set of equations based on laboratory experiments.

$$
\left(F r_{1}-F r_{c}\right)>0.2
$$

For

$$
d_{s}=2.0 b\left(F r_{1}-F r_{c}\right)^{0.25}(y / b)^{0.5}
$$

Where,

$F r_{c}$ is critical Froude Number and $d_{s}, F r_{l}, y$ and $b$ are as defined before. 
For

$$
\left(F r_{1}-F r_{c}\right)<0
$$

$$
d_{s}=1.85 b\left(F r_{c}\right)^{0.25}(y / b)^{0.3}
$$

For $0<\left(F r_{1}-F r_{c}\right)<0.2$, the larger of the two scour depths computed from the above equations is used.

Laboratory Model, Field Data and Statistical Test: In this study, laboratory experiments were carried out using glass sided tilted flume located in the hydraulic laboratory of the Department of Civil Engineering, University Putra Malaysia, Serdang, Malaysia. The flume was $450 \mathrm{~cm}$ long, $8 \mathrm{~cm}$ wide and $24 \mathrm{~cm}$ deep. Sand with $d_{50}$ of $1 \mathrm{~mm}$ was used to fill the channel, up to depth of $10 \mathrm{~cm}$. Pier models of different shapes and sizes were fixed at the center of the flume width. Pier shapes were square nose, sharp nose, and circular cylindrical, whilst the piers width used were 1, 2, 3, 4 and $5 \mathrm{~cm}$. The objective of the laboratory experiment was to collect reliable data for piers of different width and shapes to validate the above-mentioned four selected formulae in predicting local scour depth. Most of the published data is concerning a pier of single shape. A total of 45 test runs were conducted on the various pier models with different flow conditions. For each run, water discharge, flow depth, average velocity and maximum scour depth were measured. Figure 1 shows a schematic profile for the flume with a pier model.

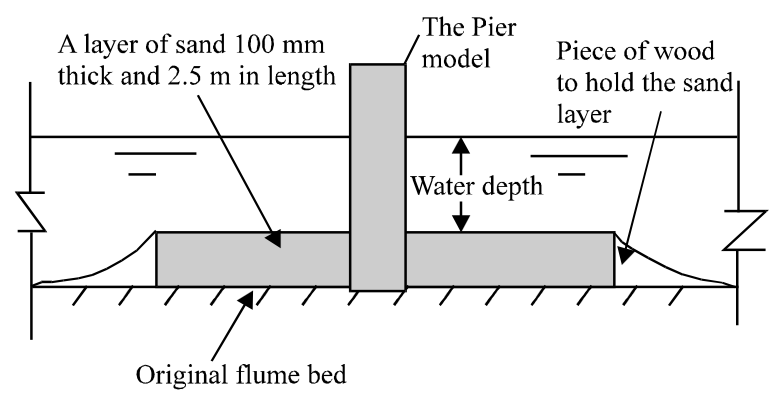

Fig. 1: Schematic Profile for the Flume and Pier Model

The field data used in this study was obtained from 14 bridges sites that had experienced local scour in three countries, namely in Canada, India and Pakistan [10]. The field data mainly include the discharge of the river at the bridge site, water depth, river width, mean approach velocity, size of the sediment carried by the flowing water, width of the piers, and maximum local scour depth. The unavailability of the recorded data of local scour for bridges in Malaysia is the main reason for considering field data related to bridges in other countries. In this study, the experimental setup is designed to study the effect of pier shape and pier width on scour depth.

Statistical tests were conducted to evaluate the predicted scour depths at pier location for both the physical model and the studied bridges. The predicted scour depths that were obtained from the application of the selected formulae and both the experimental and field data were all used in computing the parameters of the statistical tests. The statistical tests include the Theil's coefficient, U, Mean Absolute Error (MAE), and Root Mean Square Error (RMSE) that mathematically are described by Equations (6-8), respectively.

$$
U=\frac{\left[\frac{1}{n} \sum\left\{\left(d_{s}\right)_{c}-\left(d_{s}\right)_{o}\right\}^{2}\right]^{\frac{1}{2}}}{\left[\frac{1}{n} \sum_{i=1}^{n}\left(d_{s}\right)_{c}^{2}\right]^{\frac{1}{2}}+\left[\frac{1}{n} \sum\left(d_{s}\right)_{o}^{2}\right]}
$$

Where $U$ is Theil's coefficient ( $U=0$ for model of perfect prediction and $U=1$ for unsuccessful model). $\left(d_{s}\right)_{o}$ is scour depth obtained from experiments or field observation and $\left(d_{s}\right)_{c}$ is the corresponding predicted scour obtained from the application of the selected scour formulae.

MAE $=\sum_{i=1}^{n}\left|e_{i}\right| / n$
$R M S E=\sqrt{\frac{\sum_{i}^{n} e_{i}^{2}}{n}}$

where, $e_{i}$ is the error in the predicted scour depth for $i^{t h}$ event of the record from the application of the formula and $\mathrm{n}$ is number of records. The smaller values of $\mathrm{U}$, MAE and RMSE obtained from Equations (6-8) indicate a successful prediction.

\section{RESULTS AND DISCUSSION}

Figures 2-5 show scattergrams for both the predicted and measured scour depths obtained from the application of the selected formulae and laboratory experiments, respectively. The scattered points of these figures can be compared with the line of perfect agreement in order to evaluate the prediction accuracy of each formula. It appears that the Laursen and Toch and the CSU formulae give reasonable prediction, while the Melville and Sutherland and the Jain and Fisher formulae appear to over-predict the depth of the scour. This observation is supported by the statistical tests conducted on above formulae and shown in Table 2.

The maximum absolute error between the predicted scour depths obtained from the Laursen and Toch formula and that measured from the laboratory experiments was $4.05 \mathrm{~cm}$, whilst the minimum absolute error was $0.01 \mathrm{~cm}$, as summarized in Table 3 .

Figures 6-9 show the scattergrams of the both predicted and recorded scour depths obtained from the formulae 
and the field data respectively. As for the case of the laboratory experiments, it appears that the Laursen and Toch and the CSU formulae give reasonable prediction, while the Melville and Southerland and the Jain and Fisher formulae appear to over-predict the depth of the scour. This observation is also supported by the statistical tests conducted on the four selected formulae shown in Table 2. The maximum absolute error between the field recorded scoured depths and the computed scour depths using the CSU formula was $3.15 \mathrm{~m}$, whilst the minimum absolute error was $0.14 \mathrm{~m}$ (Table 4).

Table 2: Summary of the Statistical Tests on the Selected Formulae

\begin{tabular}{|c|c|c|c|c|c|c|}
\hline \multirow{2}{*}{ Scour Equation } & \multicolumn{2}{|c|}{$\begin{array}{l}\text { Theil's } \\
\text { Coefficient, U }\end{array}$} & \multicolumn{2}{|c|}{$\begin{array}{l}\text { Mean Absolute } \\
\text { Error, MAE }\end{array}$} & \multicolumn{2}{|c|}{$\begin{array}{l}\text { Root Mean Square Error, } \\
\text { RMSE }\end{array}$} \\
\hline & $\begin{array}{l}\text { Field } \\
\text { data }\end{array}$ & $\begin{array}{l}\text { Lab. } \\
\text { Data }\end{array}$ & $\begin{array}{l}\text { Field } \\
\text { data }\end{array}$ & $\begin{array}{l}\text { Lab. } \\
\text { Data }\end{array}$ & Field data & Lab. data \\
\hline Colorado State University, CSU & 0.060 & 0.214 & 0.93 & 1.013 & 1.24 & 1.61 \\
\hline Melville and Sutherland $M$ \& S & 0.121 & 0.246 & 2.43 & 1.267 & 2.88 & 1.93 \\
\hline Jain and Fisher, J \& F & 0.075 & 0.23 & 1.40 & 1.25 & 1.62 & 2.11 \\
\hline Laursen and Toch, L \& T & 0.060 & 0.210 & 1.04 & 0.095 & 1.29 & 1.32 \\
\hline
\end{tabular}

*The figure in bold indicates the smallest value (best prediction)

Table 3: Comparison of Measured and Computed Local Scour Depths for Selected Laboratory Data

\begin{tabular}{|c|c|c|c|c|}
\hline $\begin{array}{l}\text { Pier } \\
\text { width }(\mathrm{cm})\end{array}$ & $\begin{array}{l}\text { Pier } \\
\text { Shape }\end{array}$ & $\begin{array}{l}\text { Mean approach } \\
\text { Velocity }\left(\mathrm{cm} \mathrm{s}^{-1}\right)\end{array}$ & $\begin{array}{l}\text { Froud } \\
\text { Number(Fr) }\end{array}$ & $\begin{array}{l}\text { Measured scour } \\
\text { death }\left(d_{s}\right)_{m}(\mathrm{~cm})\end{array}$ \\
\hline 1 & Circular & 30.8 & 0.98 & 1 \\
\hline 2 & Circular & 30.8 & 0.98 & 1 \\
\hline 3 & Circular & 30.8 & 0.98 & 1 \\
\hline 4 & Circular & 30.8 & 0.98 & 1.1 \\
\hline 5 & Circular & 30.8 & 0.98 & 1.2 \\
\hline 1 & Square & 32.71 & 0.79 & 1.4 \\
\hline 2 & Square & 32.71 & 0.79 & 1.5 \\
\hline 3 & Square & 32.71 & 0.79 & 1.7 \\
\hline 4 & Square & 32.71 & 0.79 & 1.75 \\
\hline 5 & Square & 32.71 & 0.79 & 1.8 \\
\hline 1 & Sharp nose & 35.4 & 0.72 & 2.1 \\
\hline 2 & Sharp nose & 35.4 & 0.72 & 2.45 \\
\hline 3 & Sharp nose & 35.4 & 0.72 & 2.45 \\
\hline 4 & Sharp nose & 35.4 & 0.72 & 2.45 \\
\hline 5 & Sharp nose & 35.4 & 0.72 & 2.6 \\
\hline $\begin{array}{l}\text { Pier } \\
\text { width }(\mathrm{cm})\end{array}$ & $\begin{array}{l}\text { Scour Depth } \\
\text { applying CSU } \\
\text { Formula }\left(d_{s}\right)_{c}(\mathrm{~cm})\end{array}$ & $\begin{array}{l}\text { Scour Depth } \\
\text { applying } M \text { and } S \\
\text { Formula }\left(d_{s}\right)_{c}(\mathrm{~cm})\end{array}$ & $\begin{array}{l}\text { Scour Depth } \\
\text { applying } J \text { and } F \\
\text { Formula }\left(\mathrm{d}_{\mathrm{s}}\right)_{\mathrm{c}}(\mathrm{cm})\end{array}$ & $\begin{array}{l}\text { Scour Depth } \\
\text { applying } \mathrm{L} \text { and } \mathrm{T} \\
\text { Formula }\left(\mathrm{d}_{\mathrm{s}}\right)_{\mathrm{c}}(\mathrm{cm})\end{array}$ \\
\hline 1 & 1.99 & 2.9 & 1.76 & 1.35 \\
\hline 2 & 3.12 & 3.87 & 2.86 & 2.19 \\
\hline 3 & 4.06 & 4.3 & 3.8 & 2.91 \\
\hline 4 & 4.95 & 5.73 & 4.65 & 3.67 \\
\hline 5 & 5.79 & 7.17 & 5.43 & 4.4 \\
\hline 1 & 2.36 & 3.19 & 1.99 & 1.51 \\
\hline 2 & 3.79 & 4.15 & 2.86 & 2.59 \\
\hline 3 & 5.03 & 4.73 & 4.31 & 3.59 \\
\hline 4 & 6.06 & 6.31 & 5.27 & 4.39 \\
\hline 5 & 7.14 & 7.88 & 6.16 & 5.35 \\
\hline 1 & 2.1 & 2.61 & 1.99 & 1.69 \\
\hline 2 & 3.36 & 3.58 & 3.24 & 2.87 \\
\hline 3 & 4.37 & 4.87 & 4.31 & 3.81 \\
\hline 4 & 5.27 & 5.16 & 5.27 & 4.66 \\
\hline 5 & 6.14 & 6.45 & 6.16 & 5.55 \\
\hline
\end{tabular}

CSU=Colorado State University, $\mathrm{M}$ and $\mathrm{S}=$ Melville and Sutherland

$\mathrm{J}$ and $\mathrm{F}=\mathrm{Jain}$ and Fisher, $\mathrm{L}$ and $\mathrm{T}=\mathrm{Laursen}$ and Toch 
Table 4: Comparison of Measured (Field) and Computed Local Scour Depths

\begin{tabular}{|c|c|c|c|c|c|c|}
\hline $\begin{array}{l}\text { Bridge } \\
\text { Location }\end{array}$ & $\begin{array}{l}\text { Discharge } \\
\mathrm{Q} \mathrm{m}^{3} \mathrm{~s}^{-1}\end{array}$ & $\begin{array}{l}\text { Discharge per unit } \\
\text { width (q) } \mathrm{m}^{2} \mathrm{~s}^{-1}\end{array}$ & $\begin{array}{l}\text { Normal scour } \\
\text { depth }\left(D^{*}\right) \mathrm{m}\end{array}$ & $\begin{array}{l}\text { Pier Width } \\
\text { (b) } \mathrm{m}\end{array}$ & $\begin{array}{l}\text { Mean approach } \\
\text { velocity }(\mathrm{u}) \mathrm{m} \mathrm{s}^{-1}\end{array}$ & $\begin{array}{l}\text { Froude } \\
\text { Number (Fr) }\end{array}$ \\
\hline Pakistan & 2437 & 7.39 & 5.08 & 3.05 & 1.43 & 0.203 \\
\hline Pakistan & 1474 & 6.71 & 4.77 & 3.05 & 1.38 & 0.202 \\
\hline Pakistan & 5469 & 13.28 & 7.49 & 3.05 & 1.75 & 0.205 \\
\hline Pakistan & 1247 & 6.49 & 4.66 & 3.05 & 1.38 & 0.205 \\
\hline Pakistan & 1587 & 6.42 & 4.66 & 3.05 & 1.36 & 0.201 \\
\hline Pakistan & 2352 & 7.78 & 5.27 & 3.05 & 1.46 & 0.203 \\
\hline Pakistan & 4874 & 11.58 & 6.94 & 3.05 & 1.68 & 0.204 \\
\hline Pakistan & 7085 & 9.78 & 6.13 & 3.05 & 1.58 & 0.204 \\
\hline Pakistan & 2465 & 7.48 & 5.13 & 3.05 & 1.43 & 0.202 \\
\hline Pakistan & 5441 & 13.22 & 7.47 & 3.05 & 1.75 & 0.205 \\
\hline Pakistan & 4308 & 11.21 & 6.66 & 3.05 & 1.65 & 0.205 \\
\hline Canada & 567 & 10.33 & 7.05 & 1.83 & 1.46 & 0.175 \\
\hline Canada & 510 & 8.36 & 6.12 & 1.52 & 1.35 & 0.175 \\
\hline India & 3364 & 8.24 & 5.44 & 9.15 & 1.52 & 0.208 \\
\hline $\begin{array}{l}\text { Bridge } \\
\text { Location }\end{array}$ & $\begin{array}{l}\text { Observed } \\
\text { Scour depth }\left(\mathrm{d}_{\mathrm{s}}\right)_{\mathrm{o}} \mathrm{m}\end{array}$ & $\begin{array}{l}\text { Scour Depth } \\
\text { applying CSU } \\
\text { Formula }\left(d_{s}\right)_{c} m\end{array}$ & $\begin{array}{l}\text { Scour Depth } \\
\text { applying } M \text { and } S \\
\text { Formula }\left(d_{s}\right)_{c} m\end{array}$ & \multicolumn{2}{|c|}{$\begin{array}{ll}S & \begin{array}{l}\text { Scour Depth } \\
\text { applying } J \text { and } F \\
\text { Formula }\left(d_{\mathrm{s}}\right)_{\mathrm{c}} \mathrm{m}\end{array}\end{array}$} & $\begin{array}{l}\text { epth } \\
\text { g L and T } \\
\mathrm{a}\left(\mathrm{d}_{\mathrm{s}}\right)_{\mathrm{c}} \mathrm{m}\end{array}$ \\
\hline Pakistan & 11.24 & 8.75 & 11.58 & \multicolumn{2}{|c|}{10.41} & 9.88 \\
\hline Pakistan & 8.8 & 8.36 & 11.17 & \multicolumn{2}{|c|}{10.03} & 9.48 \\
\hline Pakistan & 12.44 & 11.71 & 14.67 & \multicolumn{2}{|c|}{13.38} & 12.88 \\
\hline Pakistan & 9.2 & 8.24 & 11.02 & \multicolumn{2}{|c|}{9.88} & 9.34 \\
\hline Pakistan & 9.76 & 8.21 & 11.02 & \multicolumn{2}{|c|}{9.89} & 9.34 \\
\hline Pakistan & 11.42 & 8.99 & 11.83 & \multicolumn{2}{|c|}{10.67} & 10.12 \\
\hline Pakistan & 11.22 & 11.04 & 13.98 & \multicolumn{2}{|c|}{12.72} & 12.21 \\
\hline Pakistan & 10.67 & 10.06 & 12.95 & \multicolumn{2}{|c|}{11.74} & 11.21 \\
\hline Pakistan & 9.48 & 8.81 & 11.65 & \multicolumn{2}{|c|}{10.49} & 9.94 \\
\hline Pakistan & 11.48 & 11.69 & 14.64 & \multicolumn{2}{|c|}{13.36} & 12.86 \\
\hline Pakistan & 8.71 & 10.71 & 13.63 & \multicolumn{2}{|c|}{12.38} & 11.86 \\
\hline Canada & 9.76 & 9.83 & 11.44 & \multicolumn{2}{|c|}{11.26} & 10.75 \\
\hline Canada & 8.54 & 8.46 & 9.77 & \multicolumn{2}{|c|}{9.69} & 9.24 \\
\hline India & 13.87 & 13.2 & 20.44 & \multicolumn{2}{|c|}{17.13} & 16.01 \\
\hline
\end{tabular}

CSU=Colorado State University, $\mathrm{M}$ and $\mathrm{S}=$ Melville and Sutherland

$\mathrm{J}$ and $\mathrm{F}=\mathrm{Jain}$ and Fisher, $\mathrm{L}$ and $\mathrm{T}=\mathrm{Laursen}$ and Toch

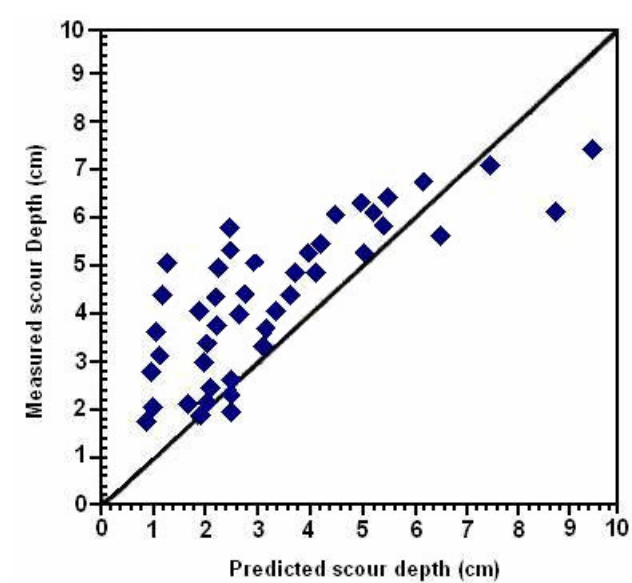

Fig. 2: Comparison Between Measured Scour Depths Obtained from Experiments and Computed Scour Depths Using CSU Formula

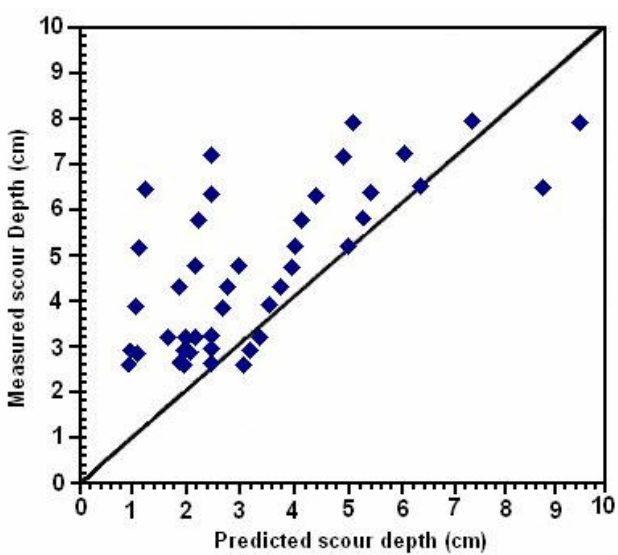

Fig. 3: Comparison of Measured Scour Depths Obtained from Experiments and Computed Scour Depths Using Melville and Sutherland Formula 


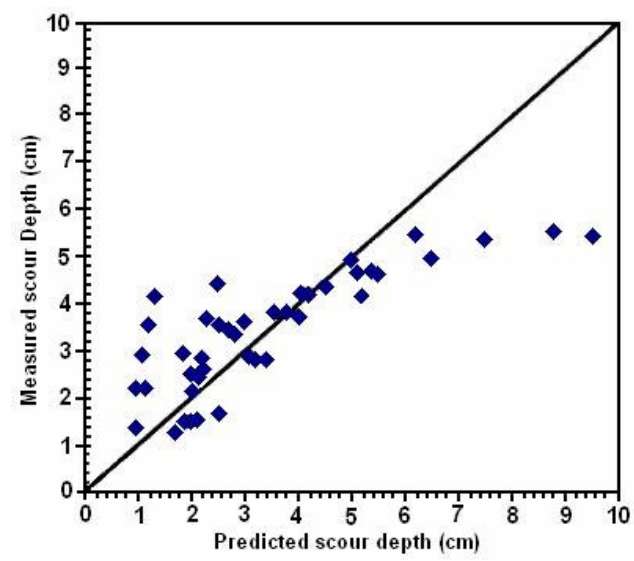

Fig. 4: Comparison of Measured Scour Depths Obtained from Experiments and Computed Scour Depths Using Laursen and Toch Formula

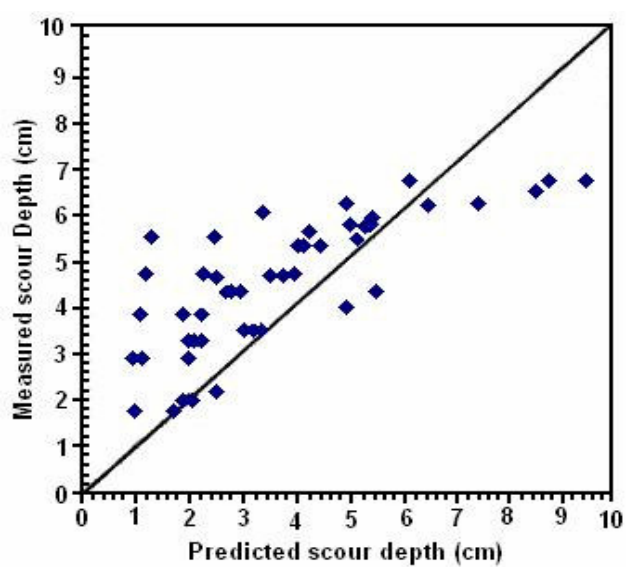

Fig. 5: Comparison of Measured Scour Depths Obtained from Experiments and Computed Scour Depths Using Jain and Fisher Formula

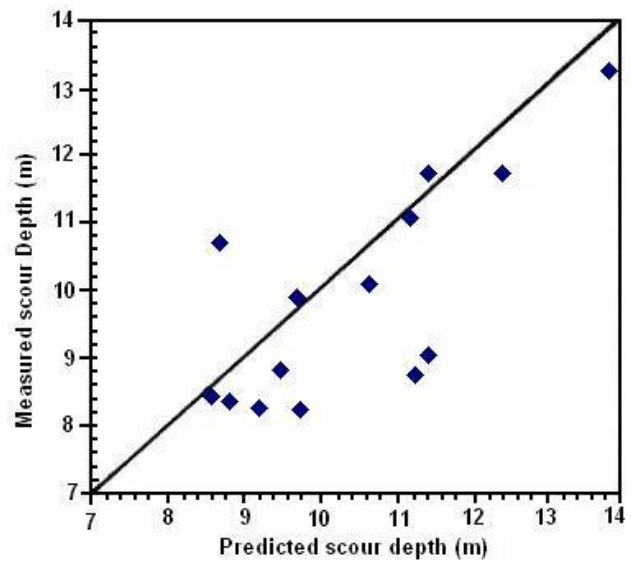

Fig. 6: Comparison of Recorded Scour Depths and Computed Scour Depths Using CSU Formula

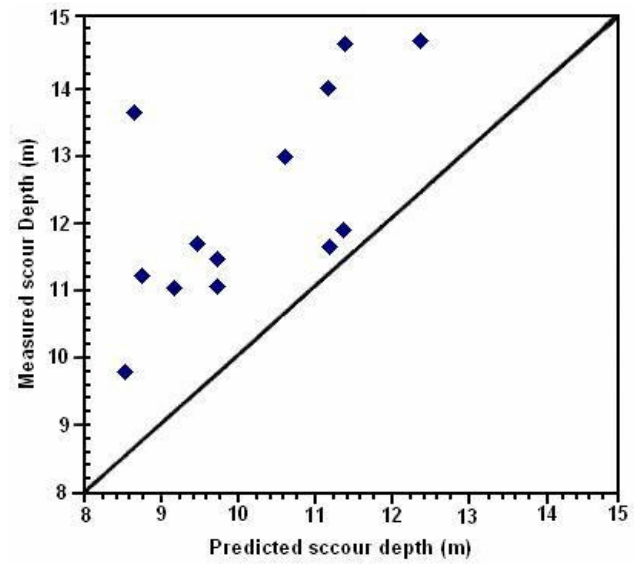

Fig. 7: Comparison of Recorded Scour Depths and Computed Scour Depths Using Melville and Sutherland Formula

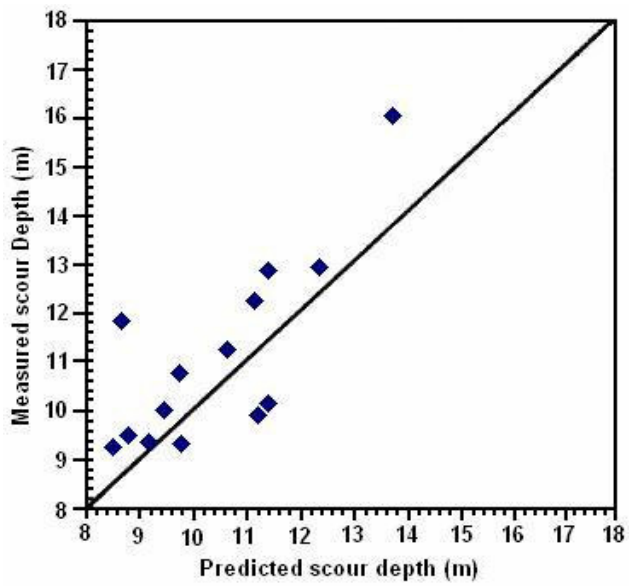

Fig. 8: Comparison of Recorded and Computed Scour Depths Using Laursen and Toch Formula

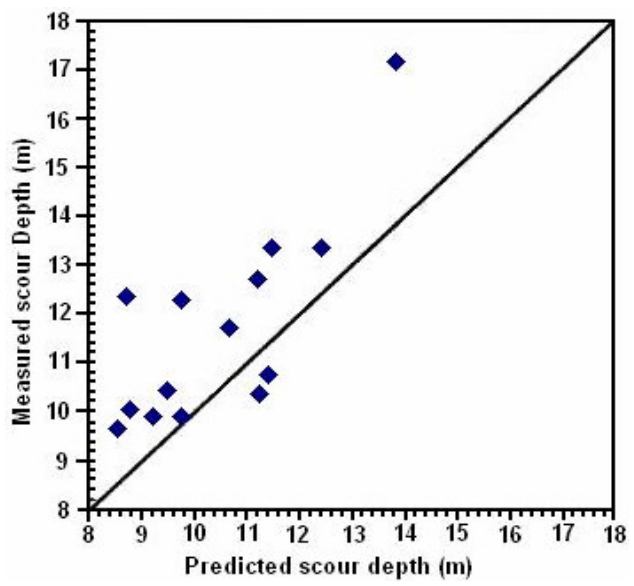

Fig. 9: Comparison of Recorded Scour Depths and Computed Scour Depths Using Jain and Fisher Formula 
Johnson [4] reported that Melville and Sutherland formula tend to over-predict the depth of the local scour to a greater extent than any of the other formulae. However, if the sediment graduation had been accounted for in the Melville and Sutherland calculations, the computed bias could have been reduced. This is also confirmed by Koopaei and Valentine [5]. From the present study, it was found that Melville and Sutherland formula over predict the depth of the local scour for both the laboratory model and field prototype. The over-prediction for the case of field prototype is even greater compared with that of the laboratory model. This is perhaps to be expected for the fact that the formulae are obtained from experimental studies employing laboratory flumes with rectangular cross section and have smooth fixed walls while most of the natural channels are non rectangular with mobile and rough banks and bed. Moreover, flow distribution through the natural channel is non-uniform. Therefore the applied formulae do not quite necessarily represent the real situation in the field $[11,12]$.

\section{CONCLUSION}

Four commonly cited formulae, namely the Colorado State University (CSU), Melville and Sutherland, Jain and Fisher, and Laursen and Toch formula used for estimating the depth of local scour at bridge piers were selected and validated using both the experimental and field data. The study shows that the Laursen and Toch and the CSU formulae appear to give a reasonable estimate of the local scour depth. While the Melville and Sutherland and the Jain and Fisher formulae appear to over-predict the scour depth. Compared with the other formulae, it appears that the Melville and Sutherland formula tend to give a greater over prediction, especially when compared with the recorded scour at the pier site of the studied bridges. The above observation was supported by the statistical tests, i.e., when the Theil's coefficient, U, Mean Absolute Error (MAE), and Root Mean Square Error (RMSE) of each of the above formulae are compared.

\section{REFERENCES}

1. U.S. Department of Transportation, 1993. Evaluating Scour at Bridges. Hydr. Engrg. Circular No. 18, Rep No. FHwA-IP-90-017, Federal Hwy. Administration (FHWA), Washington, D.C., USA.

2. Melville, B.V., 1992. Local scour at bridge abutment. J. Hydraulic Eng., ASCE, 18: 615-631.

3. Coleman, S.E. and B.W. Melville, 2001. Case study: New Zealand bridge scour experiences. J. Hydraulic Eng., ASCE, 127: 535-546.

4. Johnson, P.A., 1995. Comparison of pier scour equations using field data. J. Hydraulic Eng., ASCE, 121: 626-629.

5. Koopaei, K.B. and E.M. Valentine, 2003. Bridge pier scour in self formed laboratory channels. Technical Report, University of Glasgow, Glasgow, U.K.

6. Johnson, P.A., 1992. Reliability-based pier scour engineering. J. Hydraulic Eng., ASCE, 118: 1344-1357.

7. Simons, D.B. and F. Sentürk, 1992. Sediment Transport Technology. Water Resources Publication, Colorado, USA.

8. Melville, B.V. and A.J. Sutherland, 1988. Design method for local scour at bridge piers. J. Hydraulic Eng., ASCE, 114, 1210-1226.

9. Neill, C.R., 1964. River bed scour, A Review for Bridge Engineers. Report, Alberta, Canada.

10. Qadar, A., 1981. The vortex scour mechanism at bridge piers. J. Proc. of Inst. Civ. Engrs, Part 2, pp: 739-757.

11. Jain, S.C., 1981. Maximum clear-water scour around circular piers. J. Hydraulic Division, ASCE, 107: 611-626.

12. Raudkivi, A.J. and R. Ettema, 1983. Clear water scour at cylindrical piers. J. Hydraulic Eng., ASCE, 109: 338-350. 